\title{
PERAN MEDIASI KOMUNIKASI ATAS PENGARUH KEPEMIMPINAN TRANSFORMASIONAL TERHADAP KOMITMEN ORGANISASI PADA BANK PEMBANGUNAN DAERAH BALI
}

\author{
Gede Sunar Yoga Dharma Budi ${ }^{1}$ \\ Ni Wayan Mujiati \\ ${ }^{1,2}$ Fakultas Ekonomi dan Bisnis Universitas Udayana, Denpasar, Bali-Indonesia \\ email: sunaryoga27@gmail.com
}

\begin{abstract}
ABSTRAK
Tujuan penelitian adalah menganalisis: (1) untuk mengetahui pengaruh kepemimpinan transformasional terhadap komunikasi karyawan pada Bank Pembangunan Daerah Bali ; (2). Untuk menganalisis pengaruh kepemimpinan transformasional terhadap komitmen organisai karyawan pada Bank Pembangunan Daerah Bali; (3). Untuk menganalisis pengaruh komunikasi terhadap komitmen organisasi karyawan Bank Pembangunan Daerah Bali; (4). Untuk menjelaskan peran komunikasi dalam memediasi kepemimpinan tranformasional terhadap komitmen organisasi karyawan Bank Pembangunan Daerah Bali. Sampel ditentukan sebanyak51orang dengan teknik sampling jenuh. Pengumpulan data dilakukan dengan menyebar wawancara, observasi dan kuesioner secara langsung kepada karyawan BPD Bali dan dianalisis menggunakan statistik dekriptif rata-rata hitung serta statistik deskriptif berupa uji asumsi klasik dan analisis jalur.Hasil analisis data menunjukkan bahwa variabel kepemimpinan transformasional berpengaruh positif terhadap komunikasi karyawan, variabel kepemimpinan transformasional berpengaruh positif terhadap komitmen organisasi karyawan, variabel komunikasi berpengaruh positif terhadap komitmen organisasi karyawan, dan komunikasi berpengaruh positif dalam memediasi parsial pengaruh kepemimpinan transformasional terhadap komitmen organisasi.
\end{abstract}

Kata Kunci: kepemimpinan transformasional, komunikasi, komitmen organisasi

\begin{abstract}
The research objectives were to analyze: (1) to determine the effect of transformational leadership on employee communication at the Bali Regional Development Bank; (2). To analyze the effect of transformational leadership on employee organizational commitment at the Bali Regional Development Bank; (3). To analyze the effect of communication on the organizational commitment of Bali Regional Development Bank employees; (4). To explain the role of communication in mediating transformational leadership to the organizational commitment of Bali Regional Development Bank employees. The sample was determined as many as 51 people with saturated sampling techniques. Data collection was carried out by spreading interviews, observations and questionnaires directly to employees of the BPD Bank and analyzed using descriptive statistics calculated average and descriptive statistics in the form of a classic assumption test and path analysis. The results of the data analysis show that the transformational leadership variable has a positive effect on employee communication, the transformational leadership variable has a positive effect on the organizational commitment employees, the communication variable has a positive effect on the organizational commitment of employees, and the communication variable has a positive effect on mediate the effect of transformational leadership on organizational commitment.
\end{abstract}

Keywords: transformational leadership, communication, organizational commitment 


\section{PENDAHULUAN}

Efektifnya organisasi tergantung kepada sinergi atau kerja sama antara individu dalam organisasi dalam mencapai tujuan atau sasaran bersama. Sikap dan perilaku individu dalam organisasi semakin diperlukan untuk mendorong efektivitas organisasi yang merupakan pencapaian sasaran yang telah ditetapkan berdasarkan usaha bersama. Organisasi harus memberi perhatian yang penuh dan membuat karyawan percaya terhadap organisasi, sehingga akan diperoleh komitmen karyawan. Jika komitmen karyawan telah diperoleh akan didapatkan karyawan yang setia dan mampu bekerja sebaik mungkin untuk kepentingan organisasi. Keadaan ini sangat baik bagi pencapaian tujuan organisasi karena organisasi mendapat dukungan penuh dari anggotanya sehingga bisa berkonsentrasi secara penuh pada tujuan yang diprioritaskan.

Priansa (2014:232) menyatakan komitmen organisasional merupakan identifikasi rasa, keterlibatan, dan loyalitas yang ditampakkan oleh pegawai terhadap organisasi yang menjadi tempatnya untuk mengabdi dan bekerja.Komitmen organisasional sangat penting bagi organisasi, karena ini adalah prediktor yang baik untuk tujuan organisasi, ketidakhadiran, omset dan produktivitas (Bushra et al., 2011). Jadi Pekerja yang memiliki komitmen organisasional yang tinggi akan lebih berorientasi pada kerja, cenderung senang membantu dan dapat bekerjasama.

Komitmen organisasi karyawan dapat dipengaruhi oleh berbagai faktor, dua diantaranya yaitu komunikasi dan kepemimpinan transformasional. Robbins (2006:472) menyatakan kepemimpinan transformasional adalah jenis kepemimpinan yang terbaik karena dapat memotivasi para karyawan agar bekerja sesuai dengan tujuan yang belum pernah diraih sebelumnya, memberikan perhatian pada karyawan, mampu melatih, serta membuat karyawan loyal terhadap perusahaan. Dengan adanya gaya kepemimpinan transformasional yang sesuai dengan situasi dan kondisi organisasi maka karyawan akan lebih semangat dalam menjalankan tugas dan kewajibannya dan mempunyai perilaku dan performance dalam mengoptimalkan usaha yang lebih memuaskan kearah tercapainya visi dan misi organisasi. Penelitian Ismail dkk. (2011) menunjukkan bahwa kemampuan pemimpin dalam menunjukkan gaya transformasional dalam melaksanakan fungsi-fungsi organisasi memiliki dampak yang signifikan terhadap hasil kerja serta komitmen organisasi.

Memperkuat hubungan antara kepemimpinan transformasional dan komitmen organisasi, Hidayat (2013) dengan menambahkan faktor komunikasi organisasi. Komunikasi organisasi memegang peran penting untuk mendukung efektifitas oprasional organisasi. Aspek penting dari komunikasi organisasi adalah potensi dari komunikasi itu sendiri sebagai alat yang dapat dirancang manajemen untuk pencapaian tujuan organisasi. Pentingnya komunikasi juga dapat dilihat dari manfaat bagi organisasi meliputi fungsi pengendalian (kontrol dan pengawasan), memotivasi, pengungkapan emosional, dan penyediaan informasi untuk pengambilan keputusan (Robbins, 2009:312). Komunikasi yang terjadi didalam kelompok itu merupakan mekanisme fundamental dalam menunjukan kekecewaan atau pun rasa puas meraka. Komunikasi menyatakan ungkapan emosional dari perasaan dan pemenuhan kebutuhan sosial. Fungsi terakhir yang dilakukan oleh 
komunikasi berhubungan dengan perannya mempermudah dalam pengambilan keputusan. Mainstream studi komunikasi dalam organisasi terutama dikaitkan dengan dampak terhadap outcome bagi individu organisasi. Studi empiris menemukan bahwa efektivitas komunikasi merupakan antesenden komitmen pegawai pada organisasi, absensi, dan turnover, dan produktifitas kerja serta pereduksi ambiguitas (ambiguity) informasi bagi bawahan (Gray \& Laidlaw, 2004).

Hasil dari wawancara yang telah dilakukan peneliti terdapat beberapa masalah yang terjadi pada Bank Pembangunan Daerah Bali yaitu adanya beberapa karyawan yang masih menunggu diperintahkan untuk melakukan suatu pekerjaan tanpa adanya inisiatif dari diri sendiri, masih banyak karyawan yang tidak mematuhi peraturan perusahaan (contoh: karyawan datang terlambat ke tempat kerja), dan kurangnya rasa empati antar karyawan (contoh: beberapa karyawan yang telah selesai melakukan pekerjaan tidak mau membantu rekan kerja yang memiliki pekerjaan lebih). Masalah-masalah tersebut jika tidak diselesaikan dengan baik akan mampu mempengaruhi kinerja pada perusahaan, karena dalam perusahaan yang menyediakan fasilitas jasa sangat dibutuhkan peran sumber daya manusia yang baik.

Studi ini bertujuan untuk mengkaji keterkaitan sejumlah faktor, baik secara langsung maupun tidak langsung yang mempengaruhi komitmen organisasi. Selama ini studi perilaku organisasi, sebagian besar dilakukan pada konteks organisasi bisnis, sehingga generalisasi konstruksi-konstruksi perilaku organisasi pada konteks organisasi masih terbatas. Disadari, organisasi jenis perbankan lebih memiliki karakteristik yang khas, berbeda dengan organisasi bisnis, terutama dalam sistem dan Struktur. Akan tetapi, ditinjau dari perspektif teori perilaku organisasi, secara substansial setiap organisasi senantiasa memperjuangkan tujuan organisasi. Berdasarkan survey pendahuluan, 15 orang yang bekerja di Bank BPD, 6 orang diantaranya masih memiliki komitmen organisasi yang rendah. Hal tersebut ditunjukan oleh rasa kurang puas menjadi karyawan Bank BPD. Sejalan dengan survey pendahuluan yang telah dilakukan, maka komitmen organisasi merupakan salah satu masalah yang terjadi pada Bank BPD. Karyawan yang berstatus pegawai pada Bank BPD tahun 2017 sebanyak 51 orang karyawan. Jumlah karyawan pada Bank BPD dapat diliat pada Tabel 1.

Tabel 1.

Data Jumlah Karyawan pada Bank BPD Tahun 2017

\begin{tabular}{llc}
\hline No & Bagian & Jumlah Karyawan (orang) \\
\hline 1 & Pemimpin cabang /wapim & 2 \\
2 & Bagian pelayanan nasabah & 11 \\
3 & Bagian jasa nasabah & 8 \\
4 & Bagian pembukuan & 4 \\
5 & Bagian adm kredit/legal & 1 \\
6 & Bagian residen auditor & 4 \\
7 & Bagian umum & 7 \\
8 & Outsourching & 14 \\
& Jumlah & 51 \\
\hline
\end{tabular}

Sumber :Bank BPD Tahun 2017 
Tujuan dari Tabel ini adalah untuk mengetahui banyaknya karyawan (tenaga kerja) yang bekerja pada Bank BPD yang membantu kelancaran perusahaan dalam mencapai tujuannya. Studi ini mengkaji dan meneliti kembali outcome dari perilaku anggota dengan kerangka konseptual yang lebih komprehensif, studi ini diharapkan dapat memberikan hasil yang lebih komprehensif tentang peran komunikasi memediasi pengaruh komitmen organisasi terhadap kepemimpinan tranformasional pada Bank pembangunan daerah bali.

Berdasarkan latar belakang masalah, maka dapat dirumuskan pokok masalah sebagai berikut. 1)Bagaimanakah pengaruh kepemimpinan transformasional terhadap komitmen organisasi?. 2)Bagaimanakah pengaruh kepemimpinan transformasional terhadap komunikasi organisasi?. 3)Bagaimanakah pengaruh dari komunikasi terhadap komitmen organisasi?. 4)Bagaimanakah peran komunikasi dalam memediasi hubungan kepemimpinan tranformasional dengan komitmen organisasi?

Berdasarkam rumusan masalah di atas, maka tujuan dari penelitian ini adalah sebagai berikut. 1)Untuk mengetahui pengaruh kepemimpinan transformasional terhadap komitmen organisasi. 2)Untuk mengetahui pengaruh kepemimpinan transformasional terhadap komunikasi organisasi. 3)Untuk mengetahui pengaruh dari komunikasi terhadap komitmen organisasi. 4)Untuk mengetahui peran komunikasi dalam memediasi hubungan kepemimpinan transformasional dengan komitmen organisasi.

Sedangkan kegunaan dari penelitian ini diharapan mampu memberikan manfaat baik secara teoritis maupun praktis bagi pihak-pihak yang memiliki kaitan dengan penelitian ini, antara lain. Bagi khasanah ilmu pengetahuan, penelitian diharapkan dapat memperkaya bukti empiris dalam bidang ilmu manajemen sumber daya manusia, khususnya dalam aspek komunikasi, komitmen organisasi, dan kepemimpinan transformasional. Hasil penelitian ini juga diharapkan dapat memberikan informasi kepada pihak-pihak sebagai berikut. Penelitian ini diharapkan dapat memberikan masukan bagi Bank dalam menjalankan fungsi perusahaan, khususnya dalam hal kinerja pegawai agar dapat lebih terus ditingkatkan. Hasil penelitian ini diharapkan dapat memberi masukan yang berguna bagi pihak-pihak lain yang bersangkutan dan penelitian selanjutnya di kabupaten atau kota lain diseluruh Indonesia, dan kegunaan tersebut dapat berdampak baik bersifat praktis maupun teoritis.

Mohamed (2012) menyebutkan bahwa komitmen organisasional merujuk kepada kesiapan karyawan untuk bekerja keras, menerima dan mewujudkan tujuan organisasi, standar organisasi, prinsip organisasi, etika organisasi dan nilainilai organisasi untuk tetap berada dalam organnisasi dengan segala situasi dan kondisi. Komitmen organisasiona karyawan dapat terbentuk dengan adanya penerapan gaya kepemimpinan transformasional pada suatu organisasi atau perusahaan.

Kepemimpinan transformasional adalah kepemimpinan yang peka terhadap perubahan yang terjadi di lingkungan sekitar serta mampu untuk melakukan perubahan kearah pengembangan organisasi. Kepemimpinan transformasional berangkat dari keinginan kuat untuk mentransformasi organisasi menuju perubahan dan perbaikan, hal itu dilakukan dengan melakukan stimulasi, 
motivasi, menginspirasi dan memberikan perhatian yang individu kepada anggota yang dipimpinnya (Karim, 2010:35). Terdapat pengaruh yang signifikan antara variabel kepemimpinan terhadap komitmen organisasi (Desianty, 2005). Dalam hal ini kepemimpinan memiliki pengaruh yang lebih besar terhadap komitmen organisasi karena pemimpin lebih memberikan perhatian, dorongan motivasi dan mampu memahami keinginan karyawannya. Yang menyimpulkan bahwa efektivitas kepemimpinan berpengaruh secara signifikan terhadap komitmen organisasi (Raja \& Palanichamy, 2013). Lee (2010) juga mengamati bahwa gaya kepemimpinan memiliki pengaruh positif dan signifikan terhadap komitmen organisasi. Hidayat (2013) menjabarkan karyawan yang menilai atasan mereka memiliki praktik kepemimpinan yang buruk menyebabkan seorang karyawan memiliki kecenderungan yang lebih tinggi untuk keluar atau penurunan komitmen karyawan terhadp organisasi. Seorang pemimpin harus mampu mengubah persaingan usaha dengan mendapatkan dukungan dari karyawan yang memiliki komitmen organisasi yang tinggi dalam mencapai tujuan perusahaan. Berdasarkan uraian diatas, maka hipotesis penelitian ini adalah sebagai berikut.

$\mathrm{H}_{1}$ : Kepemimpinan transformasional $\left(\mathrm{X}_{1}\right)$ berpengaruh positif dan signifikan terhadap komitmen organisasi $\left(\mathrm{Y}_{1}\right)$.

Menurut Hidayat (2013), meningkatnya kemampuan kepemimpinan akan makin meningkatkan komunikasi organisasi. Dalam penelitian ini, kepemimpinan tercermin dalam delapan indikator, yaitu kompetensi, perlakuan yang adil, iklim kerja, ide atasan, perhatian, pelibatan bawahan, kerjasama dan kesempatan berinteraksi. Sementara itu, komunikasi organisasi tercermin dalam delapan indikato, yaitu perspektif organisasi,umpan balik personal, integrasi organisasi, komunikasi atasan langsung, iklim organisasi, komunikasi horizontal, kualitas media, dan komunikasi bawahan (Rezaeai et al., 2012). Penelitian Ismail dkk. (2011) menunjukkan bahwa kepemimpinan organisasional berkorelasi positif dan signifikan dengan komunikasi organisasi. Faharani et al. (2011) mengatakan bahwa kepemimpinan organisasional berpengaruh positif dan signifikan terhadap komunikasi organisasi. Men (2012) membuktikan terdapat hubungan positif antara kepemimpinan dan komunikasi organisasi. Berdasarkan uraian di atas, maka hipotesis penelitian adalah sebagai berikut.

$\mathrm{H}_{2}$ : Kepemimpinan transformasional $\left(\mathrm{X}_{1}\right)$ berpengaruh positif dan signifikan terhadap komunikasi (M).

Rezaeai et al. (2012) menyatakan bahwa komunikasi sebagai proses yang digunakan oleh manusia untuk mencari kesamaan arti lewat transmisi pesan simbolik. Kualitas komunikasi organisasi terbukti berpengaruh terhadap komitmen organisasi (Setyono, 2013). Penelitian Nur Rochim dkk. (2011), mengatakan bahwa komunikasi berpengaruh positif dan signifikan terhadap komitmen organisasi, semakin intern komunikasi tersebut maka akan mempengaruhi hubungan antara kepemimpinan dengan komitmen organisasi. Penelitian Mohamed (2012) mengatakan bahwa konflik interpersonal yang terjadi pada perusahaan akan berdampak terhadap komitmen organisasi. Komunikasi merupakan kunci dari bisnis perbankkan. Karyawan akan melakukan komunikasi yang lebih baik dengan manajfer, rekan kerja , atau dengan pelanggan. Dalam Hidayat (2013), komunikasi bekerja dengan baik antara pemimpin dan bawahan 
menyebabkan proses kinerja perusahaan dapat berjalan dengan baik. Hasil penelitin ini mendukung penelitian Gaertner \& Nollen, (2009) yang menyatakan komunikasi organisasi membantu karyawan yang menghadapi masalah dan meningkatkan keterlibatan karyawan dalam organisasi sehinggan meningkatkan komitmen organisasi. Berdasarkan uraian di atas, maka hipotesis penelitian ini adalah sebagai berikut.

$\mathrm{H}_{3}$ : Komunikasi $(\mathrm{M})$ berpengaruh positif dan signifikan terhadap Komitmen Organisasi $\left(\mathrm{Y}_{1}\right)$.

Taner et al. (2015) menyebutkan secara ringkas bahwa komunikasi sebagai instrument dari interaksi social berguna untuk mengetahui sikap dan komitmen orang lain di perusahaan. Nanda (2013) mengatakan bahwa komunikasi berpengaruh positif dan signifikan terhadap komitmen organisasi yang dipengaruhi oleh kepemimpinan. Kondisi ini menunjukkan bahwa proses kepemimpinan dapat meningkatkan komunikasi organisasi, yang pada gilirannya juga mampu meningkatkan komitmen karyawan terhadap organisasi (Hamdi \& Rajablu, 2012). Penelitian ini mendukung penelitian yang dilakukan oleh Desianty (2005) yang menyatakan bahwa kepemimpinan mempengaruh komitmen organisasi, jika anggota organisasi mendapatkan kehormatan khusus dan kepercayaan pada pimpinannya. Berdasarkan uraian di atas, maka hipotesis penelitian ini adalah sebagai berikut.

$\mathrm{H}_{4}$ : Komunikasi (M) memiliki pengaruh postif dan signifikan dalam memediasi komitmen organisasi $\left(\mathrm{Y}_{1}\right)$ terhadap kepemimpinan transformasional $\left(\mathrm{X}_{1}\right)$

Model penelitian diperoleh berdasarkan rumusan hipotesis penelitian tersebut, bentuk model penelitian pada penelitian ini yang disajikan berikut.

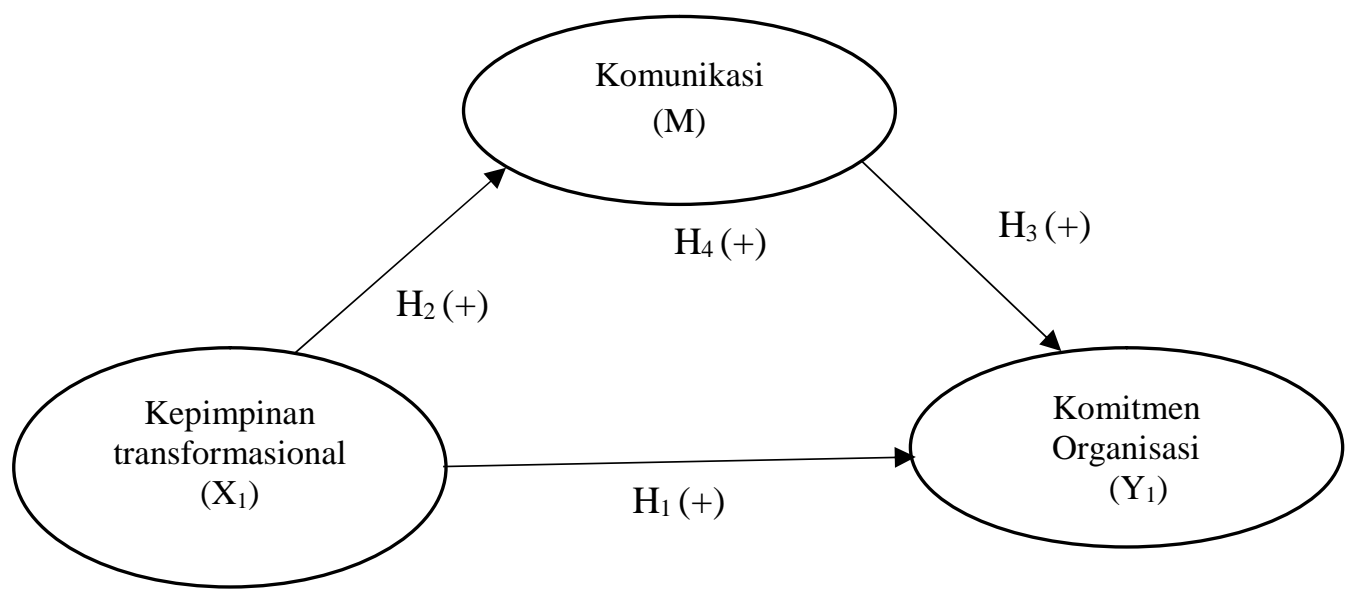

Gambar 1.Model konseptual (Conceptual Framework)

Sumber: Data diolah, 2019

\section{METODE PENELITIAN}

Hubungan yang diteliti dalam penelitian ini adalah Peran Komunikasi memediasi pengaruh Komitmen Organisasi terhadap Kepemimpinan 
Transformasional pada Bank Pembangunan Daerah, sehingga desain penelitian ini merupakan desain asosiatif. Lokasi penelitian ini di Bank BPD Bali Jl. Raya Puputan Niti Mandala,Denpasar, Bali. Alasan yang melatarbelakangi penelitian pada Bank BPD Bali adalah sebagai berikut.Bank BPD Bali sebagai Bank BUMD (Badan Usaha Milik Daerah) yang berperan lebih banyak dalam mendorong pertumbuhan sekaligus membantu program pemerintah untuk memperlancar perdagangan luar negeri. Selain itu, Bank BPD Bali merupakan bank yang sedang berkembang di wilayah Denpasar sehingga peneliti tertarik dalam meneliti perilaku para pegawai yang dapat membantu proses berkembangnya bank tersebut

Objek dari penelitian ini adalah pengaruh kepemimpinan transformasional terhadap komunikasi organisasi, pengaruh kepemimpinan transformasional terhadap komitmen organisasi, pengaruh dari komunikasi organisasi terhadap komitmen organisasi, dan peran komunikasi organisasi dalam memediasi hubungan kepemimpinan transformasional dengan komitmen organisasi.

Populasi adalah wilayah generalisasi yang terdiri atas objek atau subjek yang mempunyai kualitas dan karakteristik tertentu yang telah diterapkan oleh peneliti untuk dipelajari kemudian ditarik kesimpulannya (Sugiyono, 2010:116). Dalam penelitian ini, populasi dimaksudkan adalah seluruh pegawai Bank BPD Bali sebanyak 51 orang.

Sampel adalah sebagian dari jumlah dan karakteristik yang dimiliki oleh populasi tersebut (Sugiyono, 2010:115). Kuncoro (2003:109) mengemukakan penelitian sampel dengan mempertimbangkan (1) harus besar agar dapat mewakili populasi; (2) harus mengandung hubungan proporsional terhadap ukuran populasi. Bila populasi besar dan tidak mungkin mempelajari semua yang ada dalam populasi, misalnya karena keterbatasan dana, tenaga dan waktu maka dapat digunakan sampel yang diambil dari populasi tersebut.

Pemilihan tehnik sampling, yaitu merupakan upaya penelitian untuk mendapatkan sampel yang representatif yang dapat menggambarkan populasi.Pengambilan sampel akan dilakukan dengan tehnik samplingjenuh (populasi semua menjadi responden). Kriteria sampel pada penelitian ini adalah responden yang terdaftar sebagai pegawai Bank BPD Bali yang berjumlah 51 orang.

Jenis data yang digunakan dalam penelitian ini dikatagorikan ke dalam data kualitatif dan data kuantitatif yang dapat dijelaskan sebagai berikut: Data Kuantitatif (Sugiyono, 2010:14) adalah data yang dinyatakan dalam bentuk angka. Data kuantitatif dalam penelitian ini adalah data hasil kuesioner yang telah diberi angka dan pada masing-masing jawaban yang diperoleh dari penyebaran kuesioner. Data Kualitatif (Sugiyono, 2010:15) adalah data yang tidak dinyatakan dalam bentuk angka, seperti lokasi penelitian, dan karakteristik responden (nama dan jenis kelamin).kelamin).

Berdasarkan sumbernya (Sugiyono, 2010:193), data yang dipergunakan dalam penelitian ini adalah sebagai berikut: Sumber Primer yaitu data yang diperoleh secara langsung dari sumbernya dimana dicatat untuk pertama kalinya dan masih perlu diolah lebih lanjut agar bisa member hasil bagi penelitian. Data tersebut diperoleh melalui kuesioner penelitian mengenai peran komunikasi memediasi pengaruh komitmen organisasi terhadap kepemimpinan organisasi. 
Sumber Sekunder yaitu data yang diperoleh dan dihimpun oleh pihak lain dan perlu diolah kembali. Data Sekunder dalam penelitian ini adalah hasil penelitian terlebih dahulu dan web. Sumber sekunder pada penelitian ini berupa arsip dan informasi dari orang lain terkait mengukur variabel komitmen organisasional, kepemimpinan tranformasional dan komunikasi.

Variabel eksogen dalam penelitian ini adalah kepemimpinan transformasional yang dinotasikan dengan $\mathrm{X}_{1}$. Variabel endogen dalam penelitian ini adalah komitmen organisasi yang dinotasikan dengan $\mathrm{Y}_{1}$. Variabel Mediasi dalam penelitian ini yaitu komunikasi yang dinotasikan dengan M.Indikator yang digunakan untuk mengukur variabel penelitian ini terdapat pada Tabel 2. Berikut

Tabel 2.

\section{Indikator Variabel Penelitian}

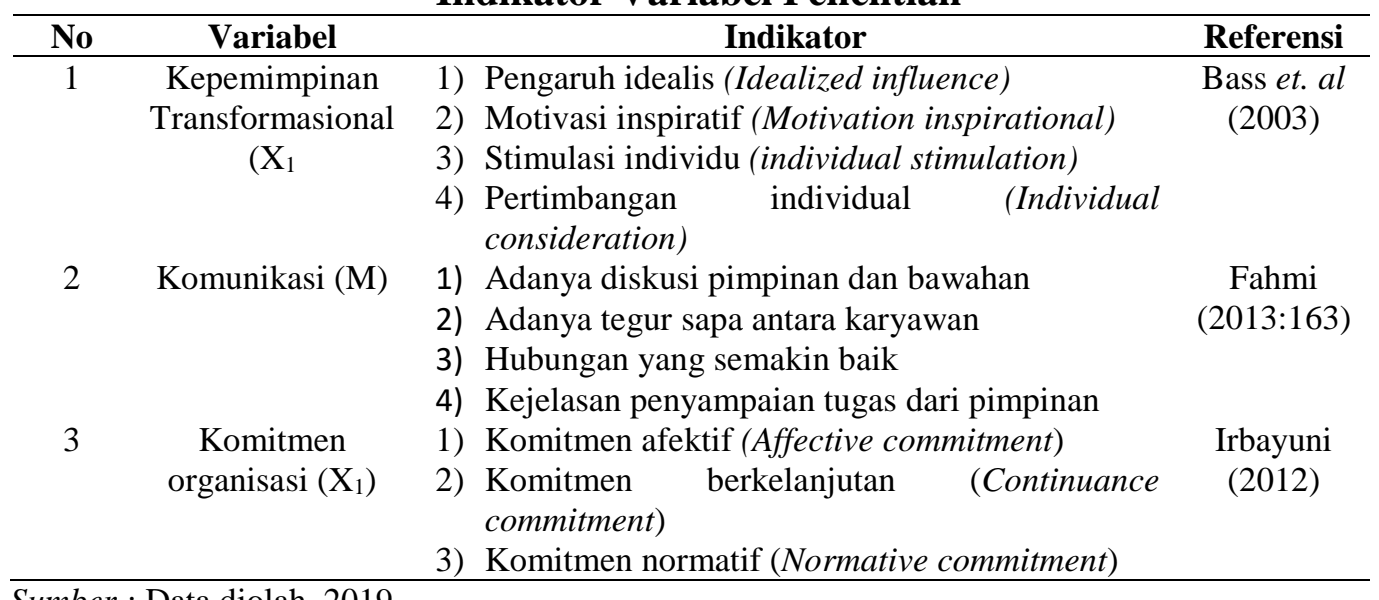

Sumber : Data diolah, 2019

Menurut Keller (1992), kepemimpinan transformasional adalah suatu proses meningkatkan motivasi pemimpin dan karyawan untuk meningkatkan kesadaran karyawan dengan mendorong idealisme nilai moral, kebebasan, keadilan, kedamaian, keseimbangan, bukan berdasarkan pada sifat emosional, ketakutan, dan kecemburuan.

Menurut Bass et al. (2003), terdapat 4 indikator dari kepemimpinan transformasional, sebagai berikut.

Pengaruh idealis (idealized influence)adalah mempunyai suatu visi yang jelas dan memiliki tujuan, maka pemimpin-pemimpin transformasional mampu untuk memenangkan kepercayaan dan respek dari para pengikut mereka. Pemimpin mampu memberikan visi dan misi, memunculkan rasa bangga karyawan. Indikator ini dapat diukur melalui persepsi responden mengenai kemampuan pemimpin membuat bawahanya bangga karena memiliki pendirian yang kuat dalam memimpin perusahaan.

Motivasi inspiratif (motivation inspirational) adalah Kemampuan pemimpin dalam memberikan dorongan agar karyawan semangat dalam bekerja. Indikator ini dapat diukur melalui persepsi responden mengenai kemampuan pemimpin dalam memberikan dorongan agar karyawan semangat dalam bekerja.

Stimulasi individu (individual stimulation) adalah Pemimpin menstimulasi 
usaha bawahannya untuk berlaku inovatif dan kreatif dalam bekerja. Indikator ini dapat diukur melalui persepsi responden mengenai usaha pemimpin untuk dapat merangsang inovasi dan kreatifitas bawahan dalam melakukan pekerjaan.

Pertimbangan individual (Individual consideration) adalah Pemimpin transformasional memberikan perhatian khusus pada kebutuhan setiap individu untuk berprestasi dan berkembang, dengan jalan sebagai pelatih, dan fasilitator. Indikator ini dapat diukur melalui persepsi responden mengenai kemampuan pemimpin untuk memperhatikan kebutuhan bawahan.organisasinya.

Komunikasi adalah suatu proses penyampaian dan penerimaan berita atau informasi dari seseorang ke orang lain. Komunikasi dapat diukur dengan indikator. 1)Adanya diskusi pimpinan dan bawahan adalah bagaimana perusahan mengadakan diskusi antara pimpinan dan bawahan sehingga komunikasi terjalin. Indikator ini diukur dari penilaian responden terhadap adanya diskusi pimpinan dan bawahan. 2)Adanya tegur sapa antara karyawan adalah terjadi tegur sapa antara karyawan dalam perusahaan sehingga komunikasi terjalin. Indikator ini diukur dari penilaian responden terhadap adanya tegur sapa antara karyawan. 3)Hubungan yang semakin baik adalah bagaimana dalam perusahaan tercipta hubungan yang semakin baik antara karyawan dan atasan atau sesame karyawan sehingga komunikasi terjalin. Indikator ini diukur dari penilaian responden terhadap hubungan yang makin baik. 4)Kejelasan penyampaian tugas dari pimpinan adalah pimpinan memberikan kejelasan penyampaian tugas kepada karyawan sehingga komunikasi terjalin. Indikator ini diukur dari penilaian responden terhadap kejelasan penyampaian tugas dari pimpinan.

Luthans (2006:249) menyatakan bahwa komitmen organisaional merupakan sikap yang menunjukan loyalitas karyawan dan merupakan proses berkelanjutan bagaimana seorang anggota organisasi mengekpresikan perhatian mereka kepada kesuksesan dan kebaikan organisasinya.

Menurut Meyer \& Allen (1991), terdapat 3 indikator dan Irbayuni (2012) 2 indikator dari komitmen organisasional, sebagai berikut.

Komitmen afektif (affective commitment) adalah perasaaan cinta pada suatu organisasi yang memunculkan kemauan untuk tetap tinggal dan membina hubungan sosial serta menghargai nilai hubungan dengan organisasi dikarenakan telah menjadi anggota organisasi. Komitmen ini merupakan hubungan emosional anggota terhadap organisasinya, identifikasi dengan organisasinya, dan keterlibatan anggota dengan kegiatan organisasinya. Indikator ini dapat diukur dari persepsi responden terhadap keterlibatan emosional terhadap organisasinya.

Komitmen berkelanjutan (continuance commitment) adalah perasaan berat untuk meninggalkan organisasi dikarenakan kebutuhan untuk bertahan dengan pertimbangan biaya apabila meninggalkan organisasi dan penghargaan yang berkenaan dengan partisipasi di dalam organisasi. Komitmen ini merupakan kesadaran anggota organisasi bahwa jika meninggalkan organisasi, maka ia akan mengalami kerugian. Indikator ini dapat diukur dari persepsi responden atas keuntungan dan resiko yang didapatkan ketika meninggalkan organisasi.

Komitmen normatif (normative commitment) adalah perasaan yang mengharuskan untuk bertahan dalam organisasi dikarenakan kewajiban dan tanggung jawab terhadap organisasi yang didasari atas pertimbangan norma, nilai 
dan keyakinan karyawan. Komitmen ini merupakan perasaan yang menggambarkan keterikatan untuk terus berada dalam organisasi. indikator ini dapat diukur dari persepsi responden terhadap sebuah dimensi moral yang didasarkan pada kewajiban dan tanggung jawab terhadap organisasi.

Kemauan merupakan keinginan dan niat untuk bekerja secara maksimal dalam mencapai target perusahaan, indikator ini diukur dari keinginan kerja karyawan bekerja secara maksimal untuk mecapai target perusahaan. Kesetiaan ditujukan dengan karyawan tidak ingin pindah kerja dari perusahaan tersebut karena adanya rasa tanggung jawab, indikator ini diukur dari keinginan karyawan untuk tetap tinggal dalam organisasi.

Pengumpulan data dalam penelitian ini dilakukan dengan menggunakan metode wawancara yaitu dengan cara tanya jawab secara langsung dengan beberapa pegawaiBank BPD bali untuk mengungkapkan Komunikasi ,Kepemimpinan transformasional dan Komitmen Organisasional. Kemudian menggunakan metode Observasi, yaitu pengumpulan data dengan cara mengadakan pengamatan langsung ke Bank Pembangunan Daerah Bali terhadap obyek yang diteliti. Serta Metode survey dilakukan dengan alat bantu berupa kuisioner sebagai alat pengumpulan data. Kuisioner dilakukan dengan cara memberikan daftar pertanyaan tertulis mengenaikomunikasi, kepemimpinan transformasional dan komitmen organisasional kepada responden yaitu seluruh pegawai BPD Bali.

Skala pengukuran yang digunakan dalam penelitian ini diukur dengan menggunakan skala Likert dengan lima tingkatan. Dalam hal ini menggunakan asumsi bahwa skala Likert menghasilkan pengukuran variabel dalam skala interval. Skala Likert digunakan untuk mengukur sikap, pendapat, dan presepsi seseorang atau sekelompok orang tentang skala sosial di mana jawaban setiap pertanyaan memiliki sejumlah katagori yang berturut-turut dari yang paling positif sampai yang paling negative. Pada skala Likert kemungkinan jawaban tidak hanya sekedar setuju dan tidak setuju atau jenis jawaban lain yang hanya memiliki dua alternative melainkan dibuat dengan lebih banyak jawaban. Alasan lain pemilihan skala Likert dengan lima tingkatan ini antara lain:Kesesuaian dengan berbagai penelitian sebelumnya, memperbesar variasi jawaban bila dibandingkan empat skala, dan agar terlihat kecenderungan pemilihan responden terhadap variabel. Masing-masing alternative jawaban pada variabel diberi skor numerik: Sangat setuju diberi skor (5), Setuju diberi skor (4), Netral diberi skor (3), Tidak setuju diberi skor (2), Sangat tidak setuju diberi skor (1).

Statistik deskriptif digunakan untuk mendeskripsikan profil responden dan variabel-variabel penelitian. Dalam hal ini digunakan rata-rata hitung dan tabel distribusi frekuensi tunggal. Wirawan (2014:33) memaparkan, untuk mendeskripsikan penilaian responden mengenai variabel-variabel dalam penelitian perlu dilakukan penentuan distribusi frekuensi berdasarkan nilai intervalnya, adapun formula untuk menentukan nilai interval yang dimaksud sebagai berikut:

Interval $=$ Nilai Tertinggi - Nilai Terendah

Jumlah kelas 
Skor penilaian terhadap butir-butir indikator variabel pada penelitian ini memilikinilai tertinggi sebesar 5 dan minimal 1, maka dapat dihitunginterval yang dimaksud dengan menggunakan formula diatas.

$$
\text { Interval }=\frac{5-1}{5}=0,8
$$

Membandingkan nilai yang didapat dengan skor yang ada didalam penelitian ini, maka akan diperoleh rata-rata skor yang ada berdasarkan kriteria sebagai berikut:

$$
\begin{array}{ll}
1,00-1,80 & =\text { Sangat Buruk } \\
1,81-2,60 & =\text { Buruk } \\
2,61-3,40 & =\text { Cukup Baik } \\
3,41-4,20 & =\text { Baik } \\
4,21-5,00 & =\text { Sangat Baik }
\end{array}
$$

Penelitian ini menggunakan teknik analisis jalur atau path analysis. Analisis jalur (path analysis) adalah perluasan dari analisis regresi linier berganda, dimana pengembangan disini berupa penerapan variabel mediasi. Variabel mediasi merupakan variabel yang memiliki peran memediasi hubungan antara suatu variabel dengan variabel lainnya. Analisis jalur hanya dapat digunakan apabila telah memenuhi asumsi-asumsi tertentu. Menurut Ridwan \& Engkos (2011:2), analisis jalur digunakan untuk menganalisis pola hubungan antar variabel untuk mempengaruhi pengaruh langsung maupun tidak langsung seperangkat variabel bebas (eksogen) terhadap variabel terikat (endogen). Analisis jalur merupakan perluasan dari analisis regresi linear berganda, atau analisis jalur adalah penggunaan analisis regresi untuk menafsirkan kausalitas antar variabel yang telah ditentukan sebelumnya berdasarkan teori. Apa yang dapat dilakukan analisis jalur adalah menentukan pola hubungan antara 3 atau lebih variabel dan tidak dapat digunakan untuk mengkonfirmasi atau menolak hipotesis kausalitas imajener (Ghozali, 2003:160). Menurut Wibowo (2005:1) pada analisis jalur ada beberapa persyaratan dalam penggunaannya yaitu: 1) Hubungan antar variabel di dalam model adalah linier artinya perubahan yang terjadi pada variabel merupakan fungsi perubahan linier variabel lain yang bersifat kausal. 2) Variabel yang diamati mempunyai sifat aditif artinya variabel mempunyai sifat multiplikatif dan eksponensial tidak dapat dipergunakan. 3) Variabel sisa tidak berkolerasi dengan variabel yang sesudahnya (variabel regresi lainnya). 4) Variabel yang diukur berskala interval. 5) Variabel observasi diukur tanpa kesalahan (Instrument pengukuran valid dan reliable).

Tujuan menggunakan teknik analisis jalur atau path analysis untuk mengetahui pengaruh langsung variabel kepemimpinan transformasional terhadap komunikasi serta pengaruh kepemimpinan transformasional dan komunikasi terhadap komitmen organisasi. Selanjutnya pengaruh tidak langsung atau variabel mediasi dalam penelitian ini dilakukan dengan uji sobel. 


\section{HASIL DAN PEMBAHASAN}

Karakteristik respondenhasil penelitian iniberdasarkan dari penyebaran kuesioner dijelaskan secara umum dapat dilihat dari jenis kelamin, usia, tingkat pendidikan, departemen, dan masa kerja dengan jumlah responden sebanyak 51 orang. Adapun karakteristik responden dapat ditunjukkan pada Tabel 3.

Tabel 3. menunjukkan lima karakteristik dari responden yang terdiri dari umur, jenis kelamin dan tingkat pendidikan. Umur dalam responden penelitian ini mulai dari 18-27 tahun sebanyak 22 orang sebesar 43,14 persen, umur 28-37 tahun sebanyak 18 orang sebesar 35,29 persen dan umur 37 tahun keatas sebanyak 11 orangsebesar 21,57 persen. Responden pada penelitian menunjukkan bahwa jenis kelamin laki-laki berjumlah 28 orangsebesar 54,90 persen. Sedangkan jenis kelamin perempuan berjumlah 23 orangsebesar 45,10 persen.

Tabel 3.

Karakteristik Responden

\begin{tabular}{cllcc}
\hline No & Karakteristik & & $\begin{array}{c}\text { Jumlah } \\
\text { (Orang) }\end{array}$ & $\begin{array}{c}\text { Persentase } \\
(\mathbf{\%})\end{array}$ \\
\hline 1 & Umur & 18-27 Tahun & 22 & 43.14 \\
& & 28-37 Tahun & 18 & 35.29 \\
& & >37Tahun & 11 & 21.57 \\
& & Total & $\mathbf{5 1}$ & $\mathbf{1 0 0 . 0 0}$ \\
\multirow{2}{*}{ 2.jenis Kemlamin } & Laki-Laki & 28 & 54.90 \\
& & Perempuan & 23 & 45.10 \\
& & Total & $\mathbf{5 1}$ & $\mathbf{1 0 0 . 0 0}$ \\
3 & \multirow{2}{*}{ Pendidikan } & SMA/Sederajat & 15 & 29.41 \\
& & Diploma & 13 & 25.49 \\
& & Sarjana & 23 & 45.10 \\
& & Total & $\mathbf{5 1}$ & $\mathbf{1 0 0 . 0 0}$ \\
\hline
\end{tabular}

Sumber : Data diolah, 2019

Tingkat pendidikan jumlah tertinggi terletak pada tingkat pendidikan SMA yang memiliki jumlah 15 orangsebesar 29,41 persen, tingkat pendidikan diploma memiliki jumlah 13 orangsebesar 25,49 persen dan jumlah yang terendah pada tingkat pendidikan Sarjana yang memiliki jumlah 23 orangsebesar 45,10 persen

Setelah mengetahui karaktersitik responden, data kuesioner selanjutnya diuji menggunakan uji validitas dan reliabilitas untuk mengetahui kelayakan instrumen penelitian. Hasil uji instrumen penelitian disajikan pada Tabel 4.

Hasil uji validitas pada Tabel 4. Menunjukkan bahwa seluruh variabel memiliki nilai pearson correlation dengan skor total seluruh item pernyataan lebih besar dari 0,30, dan memiliki koefisien cronbach's alphayang lebih besar dari angka 0,60 sehingga menunjukkan bahwa butir-butir pernyataan dalam instrument penelitian tersebut valid dan reliabel.

Pengujian persamaan path dilakukan untuk melihat pengaruh kepemimpinan transformasional terhadap komitmen organisasi yang dilakukan dengan menggunakan program SPSS. Berdasarkan hasil olah data, maka hasil analisis 
jalur persamaan uji regresi I disajikan dalam Tabel 4. dan hasil analisis jalur persamaan uji regresi II disajikan dalam Tabel 5.

Tabel 4.

\section{Hasil Uji Validitas}

\begin{tabular}{|c|c|c|c|c|}
\hline Variabel & Indikator & $\begin{array}{c}\text { Pearson } \\
\text { Correlation }\end{array}$ & $\begin{array}{l}\text { Cronbadh's } \\
\text { Alpha }\end{array}$ & Keterangan \\
\hline \multirow{4}{*}{$\begin{array}{c}\text { Kepemimpinan } \\
\text { Transformasinaonal } \\
\text { (X) }\end{array}$} & X.1 & 0,909 & \multirow{4}{*}{0,912} & \multirow{4}{*}{$\begin{array}{l}\text { Valid dan } \\
\text { Reliabel }\end{array}$} \\
\hline & X.2 & 0,874 & & \\
\hline & X.3 & 0,881 & & \\
\hline & X.4 & 0,904 & & \\
\hline \multirow{4}{*}{ Komunikasi (M) } & M.1 & 0,877 & \multirow{4}{*}{0,922} & \multirow{4}{*}{$\begin{array}{l}\text { Valid dan } \\
\text { Reliabel }\end{array}$} \\
\hline & M.2 & 0,911 & & \\
\hline & M.3 & 0,891 & & \\
\hline & M.4 & 0,927 & & \\
\hline \multirow{5}{*}{$\begin{array}{l}\text { Komitmen Organisasi } \\
\text { (Y) }\end{array}$} & Y.1 & 0,914 & \multirow{5}{*}{0,913} & \multirow{5}{*}{$\begin{array}{l}\text { Valid dan } \\
\text { Reliabel }\end{array}$} \\
\hline & Y.2 & 0,847 & & \\
\hline & Y.3 & 0,845 & & \\
\hline & Y.4 & 0,787 & & \\
\hline & Y.5 & 0.918 & & \\
\hline
\end{tabular}

Sumber : Data diolah, 2019

Tabel 5.

Hasil Analisis Jalur Persamaan Regresi 1

\begin{tabular}{lcrr}
\hline \multicolumn{1}{c}{ Variabel } & Koefisien Regresi & T & Signifikansi \\
\hline \multicolumn{1}{c}{ Kepemimpinan Transformasional } & 0,842 & 10,941 & 0,000 \\
\hline F Hitung & & & 119,710 \\
Signifikansi & & & 0,000 \\
$\mathrm{R}_{2}$ Adjusted $\mathrm{R}_{1}$ Square & & & 0,710 \\
Sumber : Data diolah, 2019 & & & 0,704 \\
\hline
\end{tabular}

Tabel 5. menunjukkan hasil analisis jalur substruktural 1, maka persamaan strukturalnya adalah sebagai berikut: $\mathrm{M}=0,842 \mathrm{X}+\mathrm{e}_{1}$

Berdasarkan hasil analisis pengaruh Kepemimpinan Transformasional terhadap Komitmen Organisasi diperoleh nilai Sig. t sebesar 0,007 dengan nilai koefisien beta 0,419 Nilai Sig. $\mathrm{t}$ 0,007<0,05 mengindikasikan bahwa $\mathrm{H}_{0}$ ditolak dan $\mathrm{H}_{1}$ diterima. Hasil ini mempunyai arti bahwa Kepemimpinan Transformasional berpengaruh positif terhadap Komitmen Organisasi.

Tabel 6. menunjukkan hasil analisis jalur substruktural 2, maka persamaan strukturalnya adalah sebagai berikut: $\mathrm{Y}=0,419 \mathrm{X}+0,446 \mathrm{M}+\mathrm{e}_{2}$

Berdasarkan hasil analisis Pengaruh Kepemimpinan Transformasional terhadap Komunikasi. diperoleh nilai Sig. $\mathrm{t}$ sebesar 0,000 dengan nilai koefisien beta 0,842 . Nilai Sig. t $0,000<0,05$ mengindikasikan bahwa $\mathrm{H}_{0}$ ditolak dan $\mathrm{H}_{1}$ diterima. Hasil ini mempunyai arti bahwa Kepemimpinan Transformasionalberpengaruh positif terhadap Komunikasi. 
Tabel 6.

Hasil Analisis Jalur Persamaan Regresi 2

\begin{tabular}{lccr}
\hline \multicolumn{1}{c}{ Variabel } & Koefisien Regresi & T & Signifikansi \\
\hline \multicolumn{1}{c}{ Kepemimpinan Transformasional } & 0,419 & 2,812 & 0,007 \\
\multicolumn{1}{c}{ Komunikasi } & 0,446 & 2,989 & 0,004 \\
F Hitung & & & 53,382 \\
Signifikansi & & & 0,000 \\
$\mathrm{R}_{2}$ & & & 0,690 \\
Adjusted $\mathrm{R}_{2}$ Square & & 0,677 \\
\hline
\end{tabular}

Sumber : Data diolah, 2019

Berdasarkan hasil analisis pengaruh Komunikasi terhadap Komitmen Organisasi. diperoleh nilai Sig. $t$ sebesar 0,004 dengan nilai koefisien beta 0,446. Nilai Sig. t 0,004 $<0,05$ mengindikasikan bahwa $\mathrm{H}_{0}$ ditolak dan $\mathrm{H}_{1}$ diterima. Hasil ini mempunyai arti bahwa Komunikasi.berpengaruh positif terhadap Komitmen Organisasi

Berdasarkan model substruktural 1 dan substruktural 2, dapat dihitung nilai standar eror sebagai berikut.

$$
\begin{aligned}
\mathrm{Pe} & =\sqrt{1-\mathrm{R}_{1}{ }^{2}} \ldots \ldots \ldots \ldots \ldots \\
& =\sqrt{1-0,710}=0,538 \\
\mathrm{Pe} & =\sqrt{1-\mathrm{R}_{2}{ }^{2}} \ldots \ldots \ldots \ldots . \\
& =\sqrt{1-0,690}=0,556
\end{aligned}
$$

Tabel 7.

Hasil Pengujian Nilai Standar Eror

\begin{tabular}{ccc}
\hline $\begin{array}{c}\text { Hasil } \\
\text { Pengujian }\end{array}$ & $\begin{array}{c}\text { Nilai Standar } \\
\text { Eror }\end{array}$ & Keterangan \\
\hline Pe & 0,538 & $\begin{array}{c}\text { Standar eror variabel kepemimpinan transformasionale } \\
\text { Standar eror variabel kepemimpinan transformasional dan } \\
\text { kepuasan kerja e }\end{array}$ \\
Pe & 0,556 &
\end{tabular}

Tabel 7. menunjukkan hasil perhitungan pengaruh error (Pei), jadi didapatkan hasil standar error variabel kepemimpinan transformasional $\left(\mathrm{Pe}_{1}\right)$ sebesar 0,538 dan hasil standar error variabel kepemimpinan transformasional dan komunikasi $\left(\mathrm{Pe}_{2}\right)$ sebesar 0,556. Hasil koefisien determinasi total adalah sebagai berikut.

$$
\begin{aligned}
\mathrm{R}^{2}{ }_{\mathrm{m}} & =1-\left(\mathrm{Pe}_{1}\right)^{2}\left(\mathrm{Pe}_{2}\right)^{2} \ldots \ldots \\
& =1-(0,538)^{2}(0,556)^{2} \\
& =1-0,089=0,911
\end{aligned}
$$

Tabel 8. menunjukkan nilai determinasi total sebesar 0,911 mempunyai arti bahwa sebesar 91,1 persen variasi komitmen organisasi dipengaruhi oleh variasi kepemimpinan transformasional, dan komunikasi, sedangkan sisanya sebesar 8,9 persendijelaskan oleh faktor lain yang tidak dimasukkan ke dalam model. 
Tabel 8.

Hasil Pengujian Koefisien Determinasi Total

\begin{tabular}{ccc}
\hline Hasil Pengujian & $\begin{array}{c}\text { Koefisien } \\
\text { Determinasi Total }\end{array}$ & Keterangan \\
\hline $\mathrm{R}^{2} \mathrm{~m}$ & 0,911 & $\begin{array}{c}\text { Pengaruh variabel indenpenden dan variabel } \\
\text { mediasi terhadap variabel dependen secara } \\
\text { gabungan }\end{array}$ \\
\hline Sumber : Data diolah, 2019 & & $\begin{array}{c}\text { gabura } \\
\end{array}$
\end{tabular}

Sumber : Data diolah, 2019

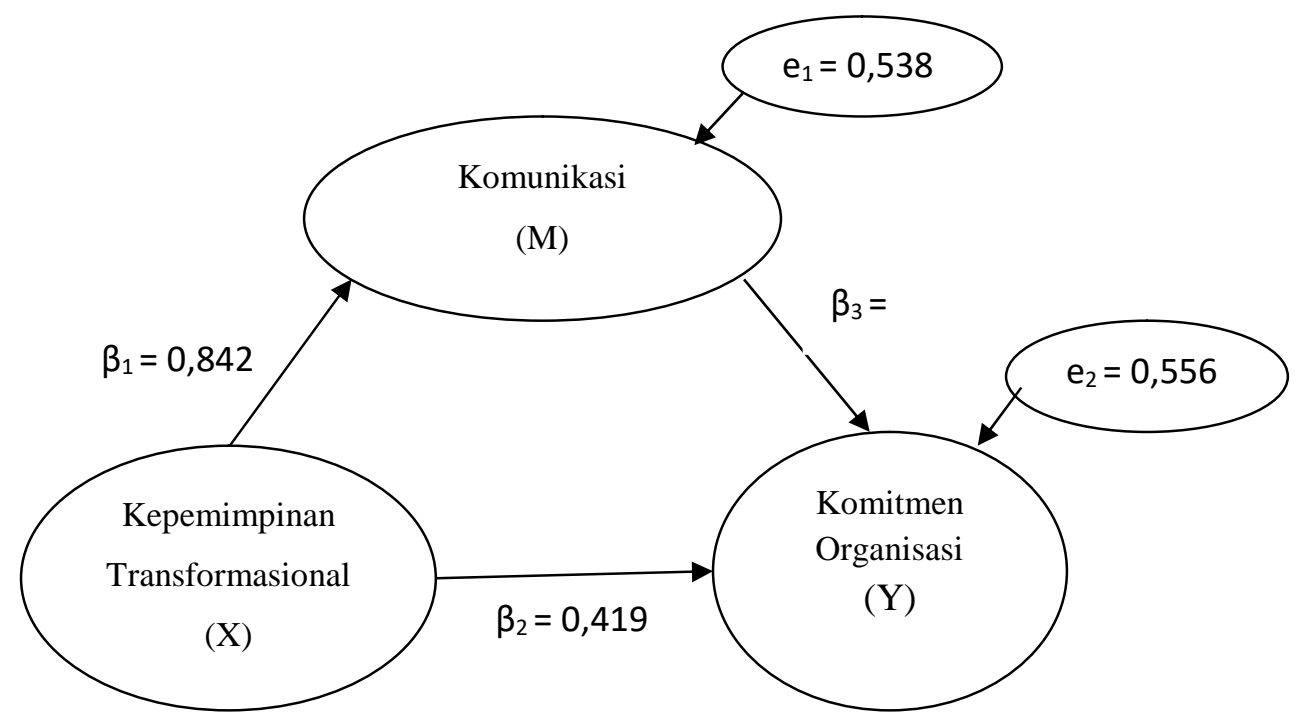

\section{Gambar 2.Validasi Model Diagram Jalur Akhir}

Sumber: data diolah, 2019

Hasil koefisien jalur pada hipotesis penelitian dapat digambarkan pada Gambar 2. Berdasarkan Gambar 2. yaitu validasi model diagram jalur akhir, maka selanjutnya dapat dihitung besarnya pengaruh langsung dan tidak langsung serta pengaruh total antar variabel. Perhitungan pengaruh masing-masing antar variabel dirangkum dalam Tabel 9.

Tabel 9. menunjukan bahwa variabel kepemimpinan transformasional memiliki pengaruh langsung terhadap komitmen organisasi dan pengaruh tidak langsung melalui komunikasi. Besarnya koefisien pengaruh tidak langsung dapat dihitung dengan mengalikan koefisien jalur dari kepemimpinan transformasional ke komunikasi dengan koefisien jalur dari komunikasi ke Komitmen Organisasi sebesar $(0,842) \times(0,446)=0,375$.

Hipotesis keempat dalam penelitian ini diuji menggunakan analisis sobel. Hasil perhitungan statistik uji variabel mediasi adalah sebagai berikut:

$$
Z=\frac{0,842 x 0,446}{\sqrt{(0,446)^{2}(0,075)^{2}+(0,842)^{2}(0,149)^{2}+(0,075)^{2}(0,149)^{2}}}
$$




$$
\begin{aligned}
& Z=\frac{0,282625}{\sqrt{0,0011+0,0157+0,0001}} \\
& Z=2,8816
\end{aligned}
$$

Tabel 9.

Pengaruh Langsung dan Pengaruh Tidak Langsung serta Pengaruh Total Kepemimpinan Transformasional (X), Komunikasi (M), dan Komitmen Organisai (Y)

\begin{tabular}{cccc}
\hline $\begin{array}{c}\text { Pengaruh } \\
\text { Variabel }\end{array}$ & $\begin{array}{c}\text { Pengaruh } \\
\text { Langsung }\end{array}$ & $\begin{array}{l}\text { Pengaruh Tidak Langsung (melalui } \\
\text { Komunikasi) }\end{array}$ & $\begin{array}{c}\text { Pengaruh } \\
\text { Total }\end{array}$ \\
\hline $\mathrm{X} \rightarrow \mathrm{M}$ & 0,842 & - & 0,665 \\
$\mathrm{X} \rightarrow \mathrm{Y}$ & 0,419 & 0,375 & 0,794 \\
$\mathrm{M} \rightarrow \mathrm{Y}$ & 0,446 & - & 0,425 \\
\hline
\end{tabular}

Sumber : data diolah, 2019

Berdasarkan hasil Uji Sobel menunjukkan bahwa hasil tabulasi $\mathrm{Z}=2,8816>$ 1,96 yang berarti variabel mediator yakni Komunikasi dinilai secara positif mampu memediasi pengaruh antara Kepemimpinan Transformasional terhadap Komitmen Organisasi

Hasil uji hipotesis menunjukkan bahwa kepemipinan transformasional berpengaruh positif signifikan terhadap komitmen organisasi. Hasil tersebut memperlihatkan bahwa semakin baik kepemimpinan transformasional pada Bank Pembangunan Daerah Balimaka akan meningkatkan komitmen organisasi karyawannya.

Hasil penelitian ini mendukung hasil dari penelitian sebelumnya yang dilakukan oleh Podsakoff et al. (1996) kepemimpinan menghasilkan komitmen organisasional dari karyawan yang lebih baik. Terdapat pengaruh yang signifikan antara variabel kepemimpinan terhadap komitmen organisasi (Desianty, 2005). Dalam hal ini kepemimpinan memiliki pengaruh yang lebih besar terhadap komitmen organisasi karena pemimpin lebih memberikan perhatian, dorongan motivasi dan mampu memahami keinginan karyawannya. Yang menyimpulkan bahwa efektivitas kepemimpinan berpengaruh secara signifikan terhadap komitmen organisasi (Raja \& Palanichamy, 2013). Lee (2010) juga mengamati bahwa gaya kepemimpinan memiliki pengaruh positif dan signifikan terhadap komitmen organisasi. Hidayat (2013) menjabarkan karyawan yang menilai atasan mereka memiliki praktik kepemimpinan yang buruk menyebabkan seorang karyawan memiliki kecenderungan yang lebih tinggi untuk keluar atau penurunan komitmen karyawan terhadp organisasi. Seorang pemimpin harus mampu mengubah persaingan usaha dengan mendapatkan dukungan dari karyawan yang memiliki komitmen organisasi yang tinggi dalam mencapai tujuan perusahaan.

Hasil uji hipotesis menunjukkan bahwa kepemimpinan transformasional berpengaruh positif dan signifikan terhadap komunikasi.Hasil tersebut memperlihatkan bahwa semakin baikkepemimpinan transformasional pada Bank Pembangunan Daerah Bali maka akan meningkatkan komunikasi yang dirasakan karyawan. 
Hasil penelitian inimendukung hasil dari penelitian sebelumnya yang dilakukan oleh Hidayat (2013), meningkatnya kemampuan kepemimpinan akan makin meningkatkan komunikasi organisasi. Dalam penelitian ini, kepemimpinan tercermin dalam delapan indikator, yaitu kompetensi, perlakuan yang adil, iklim kerja, ide atasan, perhatian, pelibatan bawahan, kerjasama dan kesempatan berinteraksi. Sementara itu, komunikasi organisasi tercermin dalam delapan indikato, yaitu perspektif organisasi,umpan balik personal, integrasi organisasi, komunikasi atasan langsung, iklim organisasi, komunikasi horizontal, kualitas media, dan komunikasi bawahan (Rezaeai et al., 2012). Penelitian Ismail dkk. (2011) menunjukkan bahwa kepemimpinan organisasional berkorelasi positif dan signifikan dengan komunikasi organisasi. Faharani et al. (2011) mengatakan bahwa kepemimpinan organisasional berpengaruh positif dan signifikan terhadap komunikasi organisasi. Men (2012) membuktikan terdapat hubungan positif antara kepemimpinan dan komunikasi organisasi.

Hasil uji hipotesis menunjukkan bahwa komunikasi yang dirasakan karyawan Bank Pembangunan Daerah Bali berpengaruh positif signifikan terhadap komitmen organisasi.Hasil tersebut memperlihatkan bahwa semakin tinggi komunikasi yang dirasakan karyawannyamaka akan meningkatkan prilaku komitmen organisasi karyawan Bank Pembangunan Daerah Bali.

Hasil penelitian ini mendukung hasil dari penelitian sebelumnya yang dilakukan oleh Setyono (2013) Kualitas komunikasi organisasi terbukti berpengaruh terhadap komitmen organisasi. Penelitian Nur Rochim dkk. (2011) mengatakan bahwa komunikasi berpengaruh positif dan signifikan terhadap komitmen organisasi, semakin intern komunikasi tersebut maka akan mempengaruhi hubungan antara kepemimpinan dengan komitmen organisasi. Penelitian Mohamed (2012) mengatakan bahwa konflik interpersonal yang terjadi pada perusahaan akan berdampak terhadap komitmen organisasi. Komunikasi merupakan kunci dari bisnis perbankkan. Karyawan akan melakukan komunikasi yang lebih baik dengan manajer, rekan kerja , atau dengan pelanggan. Dalam Hidayat (2013), komunikasi bekerja dengan baik antara pemimpin dan bawahan menyebabkan proses kinerja perusahaan dapat berjalan dengan baik. Hasil penelitin ini mendukung penelitian Gaertner \& Nollen (2009) yang menyatakan komunikasi organisasi membantu karyawan yang menghadapi masalah dan meningkatkan keterlibatan karyawan dalam organisasi sehinggan meningkatkan komitmen organisasi.

Berdasarkan hasil yang diperoleh melalui uji sobel dapat diketahui bahwa variabel komunikasidinilai secara signifikan memediasi pengaruh antara variabelkepemimpinan transformasional terhadap variabel komitmen organisasikaryawan Bank Pembangunan Daerah Bali. Hasil dalam penelitian ini mendukung hasil penelitian sebelumnya yang dilakukan oleh Gaertner \& Nollen, (2009) Komunikasi yang berjalan dengan baik antara pemimpin dan bawahan menyebabkan proses kinerja perusahaan dapat berjalan dengan baik. Komunikasi yang baik akan menyebabkan karyawan merasa seperti dirumah dan bekerja dengan motivasi tinggi dan semangat. Taner et al. (2015) menyebutkan secara ringkas bahwa komunikasi sebagai instrument dari interaksi social berguna untuk mengetahui sikap dan komitmen orang lain di perusahaan. Nanda (2013) 
mengatakan bahwa komunikasi berpengaruh positif dan signifikan terhadap komitmen organisasi yang dipengaruhi oleh kepemimpinan. Kondisi ini menunjukkan bahwa proses kepemimpinan dapat meningkatkan komunikasi organisasi, yang pada gilirannya juga mampu meningkatkan komitmen karyawan terhadap organisasi (Hamdi \& Rajablu, 2012). Penelitian ini mendukung penelitian yang dilakukan oleh Desianty (2005) yang menyatakan bahwa kepemimpinan mempengaruh komitmen organisasi, jika anggota organisasi mendapatkan kehormatan khusus dan kepercayaan pada pimpinannya.

Penelitian ini dapat memberikan informasi penting untuk Bank Pembangunan Daerah Bali agar dapat meningkatkan adanya kepemimpinan transformasional di lingkungan perusahaan yang dapat dirasakan oleh karyawannya sehingga dapat meningkatkan komunikasi yang dirasakan oleh para karyawan Bank Pembangunan Daerah Bali. Komunikasi yang semakin tinggi yang dirasakan oleh para karyawan juga mampu mendorong adanya prilaku komitmen organisasi semakin tinggi. Dengan menjaga adanya kepemimpinan transformasional di lingkungan perusahaan dan meningkatkan komunikasi yang dirasakan karyawannya, diharapkan kedepannya Bank Pembangunan Daerah Bali semakin mampu meningkatkan prilaku komitmen organisasiuntuk perusahaan. Penelitian ini juga diharapkan dapat memberikan sumbangan terhadap ilmu pengetahuan khususnnya manajemen sumber daya manusia, sekaligus memperkaya teori-teori kepemimpinan transformasional, Komunikasi, dan Komitmen Organisasi.

\section{SIMPULAN}

Simpulan dalam penelitian ini yaitu Variabel kepemimpinan transformasional berpengaruh positif dan signifikan terhadap komunikasi karyawan Bank Pembangunan Daerah Bali. Hasil tersebut membuktikan bahwa apabila semakin baik kepemimpinan transformasional yang dirasakan oleh karyawan maka akan menimbulkan komunikasi yang semakin baik pula pada benak karyawannya. Variabel komunikasi berpengaruh positif dan signifikan terhadap komitmen organisasi pada karyawan Bank Pembangunan Daerah Bali. Hasil tersebut membuktikan bahwa apabila semakin tingginya komunikasi yang dirasakan karyawan maka akan meningkatkan prilaku komitmen organisasidi lingkungan perusahaan. Variabel kepemimpinan transformasional berpengaruh positif dan signifikan terhadap komitmen organisasi karyawan Bank Pembangunan Daerah Bali. Hasil tersebut membuktikan bahwa apabila semakin tingginyakepemimpinan transformasional maka akan semakin meningkatkan prilaku komitmen organisasidi lingkungan perusahaan. Variabel komunikasi berpengaruh positif dan signifikan dalam memediasi parsial pengaruhkepemimpinan transformasional terhadap komitmen organisasi pada Bank Pembangunan Daerah Bali. Hasil tersebut membuktikan bahwa komunikasi mampu menjadi perantara antarakepemimpinan transformasional yang akan meningkatkan komitmen organisasi.

Sedangkan saran yang dapat diberikan berdasarkan hasil analisis dan pembahasan adalah sebagai berikut. Pimpinan pada Bank Pembangunan Daerah 
Bali harus lebih mampu untuk memperhatikan kebutuhan bawahannya, karena pernyataan tersebut yang mempunyai poin terendah, hal ini dapat meningkatkan kepemimpinan transformasional yang dirasakan oleh karyawannya sehingga akan berpengaruh juga pada komunikasi serta komitmen organiasi. Manajemen Bank Pembangunan Daerah Bali haruslah lebih memperhatikan tegur sapa antara karyawan dengan pimpinan terjalin dengan baik.. sehingga karyawan memiliki komunikasi yang baik terhadap pimpinan perusahaan serta meningkatkan komitmen organisasi pada perusahaan. Bagi peneliti selanjutnya, diharapkan untuk melakukan penelitian dengan cakupan yang lebih luas, menambah variabelvariabel lain di luar penelitian ini, serta diharapkan mampu menambah referensi atau sumber yang lebih banyak terhadap variabel yang akan diteliti.

\section{REFERENSI}

Bushra, F., Usman, A., \& Naveed, A. (2011). Effect of Transformational Leadership on Employees' Job Satisfaction and Organizational Commitment in Banking Sector of Lahore (Pakistan). International Journal of Business and Social Science, 2(18), 261-267.

Desianty, S. (2005). Pengaruh Gaya Kepemimpinan Terhadap Komitmen Organisasi Pada PT. Pos Indonesia (Persero) Semarang. Jurnal Studi Manajemen \& Organisasi, 2(1), 69-84.

Faharani, M., Marzieh, T., \& Mehdi, B. (2011). An Exploration of the Relationship between Transformational Leadership and Organizational Commitment: The Moderating Effect of Emotional Intelligence: Case Study in Iran. International Business Research, 4(4), 211-217.

Gaertner, K. N., \& Nollen, S. D. (2009). Career Experiences, Perceptions of Employment Practices. International Journal of Business and Management, $8(18), 52-64$.

Gray, J., \& Laidlaw, H. (2004). Improving the measurement of communication satisfaction. Management Communication Querterly, 17(3), 425-448.

Hamdi, S., \& Rajablu, M. (2012). Effect of Supervisor-Subordinate Communication and Leadership Style on Organizational Commitment of Nurse in Healt Care Setting. International Journal of Business and Management, 7(23), 7-18.

Hidayat, R. (2013). Pengaruh Kepemimpinan terhadap Komunikasi, Kepuasan Kerja, dan Komitmen Organisasi pada Industri Perbankan. Makara Seri Sosial Humaniora, 17(1), 19-32.

Ismail, A., Mohamed, H., Sulaiman, A. Z., Mohamad, M. H., \& Yusuf, M. H. (2011). An Empirical Study of the Relationship between Transformational 
Leadership, Empowerment and Organizational Commitment. Business and Economics Research Journal, 2(1), 89-107.

Karim, M. (2010). Pemimpin transformasional di lembaga pendidikan islam. Malang: UIN-Maliki press.

Lee, H. W. (2010). Relationship between leadership style and organizational commitment. Operating Management Review, 6(1), 87-95.

Men, L. (2012). The Effects of Organizational Leadership on Strategic Internal Communication and Employee Outcomes. Open Access Dissertations, 3(7), 213-225.

Mohamed, S. (2012). Relationship Between Organizational Commitment and Organizational Citizenship Behavior. The IUP Journal of Organizational Behavior, 9(3), 122-143.

Podsakoff, P. M., MacKexzie, S. B., \& Bommer, W. H. (1996). A meta-analysis of the relationships between Kerr and Jermier's substitutes for leadership and employee job attitudes, role perceptions and performance. Journal of Applied Psychology, 81(4), 380-399.

Priansa, D. (2014). Perencanaandan Pengembangan SDM. Bandung: Alfabeta.

Raja, A. S., \& Palanichamy, P. (2013). Leadership Styles and Its Impact On Organizational Commitment. The Journal of Commerce, 3(4), 15-23.

Taner, B., Mithat, T., Lter, H., \& Onur, K. (2015). The Effect of the Leadership Perception and Organizational Juctice on Organizational Commitment: A Research in State University. International Review of Management and Marketing, 5(3), 180-194. 